\title{
Mechanism of Preservation of Glomerular Perfusion and Filtration during Acute Extracellular Fluid Volume Depletion

\author{
Importance of Intrarenal Vasopressin-Prostaglandin Interaction for Protecting
} Kidneys from Constrictor Action of Vasopressin
}

\author{
Aida Yared, Valentina Kon, and lekuni Ichikawa \\ Laboratory of Renal Physiology, Department of Medicine, The Children's Hospital and Department of Pediatrics, \\ Harvard Medical School, Boston, Massachusetts 02115
}

\begin{abstract}
Glomerular circulatory dynamics were assessed in 60 adult anesthetized rats, which were either deprived or not deprived of water for 24-48 h. Water-deprived rats $(n=21)$ were characterized by a depressed level of single nephron glomerular filtration rate (SNGFR) when compared with nonwater-deprived controls $(n=8)(23.2 \pm 1.3$ vs. $44.8 \pm 4.1 \mathrm{nl} / \mathrm{min})$. This was primarily due to decreased glomerular plasma flow rate $(71 \pm 5$ vs. $169 \pm 23 \mathrm{nl} / \mathrm{min})$ and glomerular capillary ultrafiltration coefficient $(0.028 \pm 0.003$ vs. $0.087 \pm 0.011 \mathrm{nl} /[\mathrm{s} \cdot \mathrm{mmHg}])$. Infusion of saralasin to these water-deprived rats resulted in significant increases in plasma flow rate and ultrafiltration coefficient, and decline in arteriolar resistances. Consequently, SNGFR increased by $\sim 50 \%$ from pre-saralasin levels. When water-deprived saralasin-treated rats were given a specific antagonist to the vascular action of arginine vasopressin (AVP), $d\left(\mathrm{CH}_{2}\right)_{5} \mathrm{Tyr}(\mathrm{Me}) \mathrm{AVP}$, a fall in systemic blood pressure occurred, on average from $102 \pm 5$ to $80 \pm 5 \mathrm{mmHg}$, unaccompanied by dilation of renal arterioles, so that both plasma flow rate $(129 \pm 8 \mathrm{vs} .85 \pm 13 \mathrm{nl} / \mathrm{min})$ and SNGFR (31.0 \pm 2.9 vs. $18.2 \pm 4.4$ nl/min) decreased.

This more selective extrarenal constrictor action of AVP was further documented in additional studies in which cardiac output and whole kidney blood flow rate were simultaneously measured. In water-diuretic rats, administration of a moderately pressor dose of AVP (4 mU/kg per min) resulted in a significant rise in kidney blood flow rate (from 8.8 \pm 1.2 to $9.6 \pm 1.3 \mathrm{ml} / \mathrm{min}$ ). The higher kidney blood flow rate occurred despite a fall in cardiac output (from $111 \pm 7$ to $98 \pm 9 \mathrm{ml} / \mathrm{min}$ ), and was associated with a significant increase in the ratio of systemic vascular to renal vascular resistance (on average from $0.083 \pm 0.014$ to $0.106 \pm 0.019)$. Furthermore, infusion of $d\left(\mathrm{CH}_{2}\right)_{5}$ Tyr(Me)AVP to water-deprived animals $(n=6)$ to antagonize endogenous AVP resulted in systemic but not renal vasodilation, so that kidney blood flow rate fell (by $\sim 30 \%$ ), as did systemic-to-renal resistance ratio (by $\sim 30 \%$ ). When the
\end{abstract}

Portions of these studies were presented at the annual meeting of the American Federation for Clinical Research, Washington, DC, 1983; at the American Society of Nephrology, Washington, DC, 1983; and were published in abstract form (Clin. Res. 31:431, 1983; Kidney Int. 25:293, 1984.

Address correspondence to Dr. Ichikawa.

Received for publication 19 January 1984 and in revised form 3 January 1985.

J. Clin. Invest.

(c) The American Society for Clinical Investigation, Inc. $0021-9738 / 85 / 05 / 1477 / 11 \quad \$ 1.00$

Volume 75, May 1985, 1477-1487 above two experiments were repeated in indomethacin-treated animals, exogenous AVP administration in water-diuretic rats $(n=6)$ and antagonism of endogenous AVP in water-deprived rats $(n=7)$ caused, respectively, parallel constriction and dilation in systemic and renal vasculatures. The net effect was unaltered systemic to renal vascular resistance ratio in both cases. These results indicate that (1) unlike angiotensin II, AVP maintains glomerular perfusion and filtration in acute extracellular fluid volume depletion by a more selective constriction of the extrarenal vasculature. (2) The relative renal insensitivity to the vasoconstrictor action of $\mathrm{AVP}$ appears to be due to an AVP-induced release of a potent renal vasodilator, sensitive to indomethacin, presumably prostaglandins.

\section{Introduction}

Recent evidence indicates that arginine vasopressin (AVP), ${ }^{1}$ in plasma concentrations within the physiological range, exerts a critically important role in the maintenance of blood pressure and systemic circulatory dynamics (1-4). The availability of several forms of synthetic analogues to the vascular action of the hormone (1-7) has allowed experimental demonstration of this role.

In addition to its systemic effect, AVP possesses a direct vasoconstrictor action on the glomerular microcirculation. A non-pressor dose of AVP leads to a profound fall in the glomerular capillary ultrafiltration coefficient $\left(K_{f}\right)(8)$, presumably by inducing mesangial cell contraction (9). Moreover, in our recent experiments with two-kidney Goldblatt hypertension, an experimental model characterized by a high circulating level of AVP (10), a specific AVP antagonist was shown to markedly raise $K_{\mathrm{f}}$.

Of related interest are the observations (11-13) that the renal vasculature is less sensitive to the constrictor action of exogenous AVP than are some extrarenal vascular beds. The present study aims at defining the role of endogenously released

1. Abbreviations used in this paper: $\mathrm{AII}$, angiotensin II; $\overline{\mathrm{AP}}$, mean systemic arterial pressure; $\pi_{A}$, systemic plasma oncotic pressure; AVP, arginine vasopressin; $C_{A}$, systemic plasma protein concentration; $C_{E}$, efferent arteriolar plasma protein concentration; $\mathrm{CO}$, cardiac output; $E C F$, extracellular fluid; $\pi_{E}$, efferent arteriolar plasma oncotic pressure; $K_{f}$, glomerular capillary ultrafiltration coefficient; non-WD, nonwaterdeprived rats; $\mathrm{P}_{E}$, efferent arteriolar hydraulic pressure; $\overline{\mathrm{P}}_{\mathrm{GC}}$, mean glomerular capillary hydraulic pressure; $\mathbf{P}_{\mathrm{T}}$, proximal tubule hydraulic pressure; $\overline{\Delta \mathrm{P}}$, mean glomerular transcapillary hydraulic pressure difference; $Q_{A}$, initial glomerular plasma flow rate; $R_{A}$, afferent arteriolar resistance; $R B F$, whole kidney blood flow rate; $R_{E}$, efferent arteriolar resistance; RVR, renal vascular resistance; SNFF, single nephron filtration fraction; SNGFR, single nephron glomerular filtration rate; SVR, systemic vascular resistance; WD, water-deprived rats. 
AVP in determining the prevailing levels of renal perfusion and filtration during acute extracellular fluid (ECF) volume depletion. The overall functional effect of AVP on renal circulation under a given set of physiological circumstances is not readily predictable, since renal circulatory dynamics are determined by the balance between intrinsic renal and extrarenal vascular tones, as well as the level of cardiac output (CO). We therefore studied the effects of specific antagonism to the vascular action of AVP, by measuring various renal and systemic circulatory indices in water-deprived animals. To document the uniqueness of AVP action, the results were compared with the vasodilatory influence of angiotensin II (AII) inhibition, as well as that of hydralazine, a drug known to dilate both renal and extrarenal vascular beds (14). It should be noted that, although the sympathetic nervous system and circulating catecholamines likely contribute to the prevailing renal hemodynamics in volume-depleted animals, their role will not be addressed in the present study.

\section{Methods}

General. Experiments were performed in nine groups of adult male rats. Munich-Wistar rats were used for the experiments involving micropuncture (groups 1-5), and Sprague-Dawley rats in studies without micropuncture (groups 6-9). Before study, the animals were maintained on standard rat pellet chow. In groups $1-4,6$, and 7 , acute ECF depletion was induced by withholding drinking water 24-48 h before experiment. Rats in groups 5, 8, and 9 were allowed free access to water until the time of study.

At the time of study, the animals were anesthetized with Inactin (Byk, Federal Republic of Germany; $100 \mathrm{mg} / \mathrm{kg}$, i.p.), placed on a temperature-regulated table, and subjected to tracheostomy. Indwelling polyethylene catheters were inserted into the left and/or right jugular veins for infusion of various intravenous solutions as specified below. The left femoral artery was also catheterized for periodic blood sampling and estimation of mean arterial pressure $(\overline{\mathrm{AP}})$. The $\overline{\mathrm{AP}}$ was monitored with an electronic transducer (model p23Db, Statham Instruments Div., Gould, Inc., Oxnard, CA) connected to a directwriting recorder (model 2200, Gould Inc.). In group 6-9 animals, a catheter was inserted into the left ventricle through the left carotid artery for injection of radioactive microspheres. Correct placement of the catheter tip was confirmed by pressure tracing. The left kidney was exposed through a left subcostal incision and gently separated from the adrenal gland and the surrounding perirenal fat. In group 1-5 studies, the kidney was suspended on a Lucite holder, and its surface illuminated with a fiberoptic light source and bathed with isotonic $\mathrm{NaCl}$ solution heated to $35^{\circ}-37^{\circ} \mathrm{C}$. A 0.5 -ml bolus intravenous injection of $10 \%$ inulin in $0.9 \% \mathrm{NaCl}$ was given, followed by a continuous infusion at the rate of $0.6 \mathrm{ml} / \mathrm{h}$ (groups $1-4$ ) or $1.2 \mathrm{ml} / \mathrm{h}$ (group 5).

Since the plasma volume of rats prepared surgically in the above fashion is substantially reduced from the level prevailing in the conscious state (14), estimated plasma losses were replaced in group 1-9 animals with use of the formula described in detail previously (15). The amount of iso-oncotic plasma used was $\sim 1 \%$ of body weight in group 5,8 , and 9 animals, and $0.5-0.7 \%$ in group $1-4,6$, and 7 animals.

Micropuncture measurements. In group 1-5 animals, micropuncture measurements were carried out as follows: exactly timed (1-2 min) samples of tubule fluid were collected from surface proximal convolutions of two or three nephrons for determination of flow rate and inulin concentration. These measurements permitted calculation of single nephron glomerular filtration rate (SNGFR). Coincident with these tubule fluid collections, two or three samples of femoral arterial blood were obtained in each period for determination of arterial hematocrit and plasma concentrations of protein and inulin. Time averaged hydraulic pressures were measured in surface glomerular capillaries $\left(\overline{\mathbf{P}}_{\mathrm{GC}}\right)$, proximal tubules $\left(\mathrm{P}_{\mathrm{T}}\right)$, and surface efferent arterioles $\left(P_{E}\right)$ with a continuous recording, servo-null micropipette transducer system (model 3, Instrumentation for Physiology and Medicine, San Diego, CA). Micropipettes with outer tip diameters of $1-2 \mu \mathrm{m}$ and containing $2.0 \mathrm{M}$ sodium chloride were used. Hydraulic output from the servo-nulling system was coupled electronically to a second channel of the recorder.

Colloid osmotic pressure $(\pi)$ of plasma entering and leaving glomerular capillaries was estimated from values for protein concentration $(C)$ in femoral arterial $\left(C_{A}\right)$ and surface efferent arteriolar $\left(C_{E}\right)$ plasma samples by using the equation derived by Deen et al. (16). Values for $\mathrm{C}_{\mathrm{A}}$, and thus systemic plasma oncotic pressure $\left(\pi_{A}\right)$, in femoral arterial plasma were taken as representative of values for $C$ and $\pi$ at the afferent end of the glomerular capillary network. These estimates of preglomerular and postglomerular plasma protein concentrations permitted calculation of single nephron filtration fraction (SNFF) and initial glomerular plasma flow rate $\left(\mathrm{Q}_{\mathrm{A}}\right) . K_{\mathrm{f}}$, as well as resistances of single afferent $\left(R_{A}\right)$ and efferent $\left(R_{E}\right)$ arterioles, were calculated by using the equations given elsewhere (17).

Cardiac output and whole kidney blood flow rate (RBF) measurements. These two indices were measured in group 6-9 studies.

$\mathrm{CO}$ was determined with carbonized microspheres (3M Co., St. Paul, MN), $15 \pm 0.6 \mu \mathrm{m}$ in diameter, labeled with ${ }^{51} \mathrm{Cr}$. An isotonic saline solution in a volume of $50 \mu \mathrm{l}$, containing $\sim 35,000$ microspheres was placed into an 8-cm length of Silastic tube (ID 0.04 in., Dow Chemical Co., Midland, MI). The tube was capped at both ends. Its radioactivity was measured immediately before use in a Packard TriCarb solid crystal gamma radiation counter. At the time of study, the microspheres were disaggregated and flushed (with $0.3 \mathrm{ml}$ isotonic saline) into the left ventricular cavity through an indwelling catheter over a 20 -s period. Concurrently, arterial femoral blood $(\sim 1.5 \mathrm{ml})$ was collected for $30 \mathrm{~s}$ by unclamping the femoral arterial catheter and allowing the blood to flow freely into a graduated test tube. Replacement transfusion was simultaneously performed, using whole blood obtained from littermates of the experimental animals. For group 8 and 9 studies, the blood was diluted with $0.9 \% \mathrm{NaCl}$ to achieve a low serum protein concentration $(4.5-5.0 \mathrm{~g} / \mathrm{dl})$ comparable with that of the recipient animals, while keeping the hematocrit unchanged. No fluctuation of arterial pressure occurred during the procedure. Residual radioactivity in the Silastic tube and its caps was measured. Cardiac output was calculated as: $\mathrm{CO}=$ (counts injected into left ventricle)/ (counts collected in femoral arterial blood $\times$ femoral arterial blood flow rate).

Left renal arterial blood flow rate was measured with an electromagnetic flow probe (model FP402, Carolina Medical Electronics, Inc., King, NC, $2.0 \mathrm{~mm}$ in circumference) connected to an electromagnetic flow meter (model 501, Carolina Medical Electronics, Inc.). This flow meter system was calibrated in vivo (16) before use. Systemic (SVR) and renal (RVR) vascular resistances were calculated as the ratio of $\overline{\mathrm{AP}}$ to $\mathrm{CO}$ and $\mathrm{RBF}$, respectively.

Experimental groups. Animals were divided into nine groups. Groups 1-5 underwent micropuncture studies as described above, groups 1-4 being deprived of water for 24-48 h, while group 5 was allowed free access to water until the time of study. Groups 6-9 had simultaneous measurement of $\overline{\mathrm{AP}}, \mathrm{CO}$, and $\mathrm{RBF}$; again, groups 6 and 7 were water deprived for 24-48 h, while groups 8 and 9 were allowed free access to water until the time of study. Individual protocols are described in detail below, and summarized in Table $I$.

Group 1 (seven Munich-Wistar rats): The time course of renal microcirculatory and systemic dynamics of acutely water-deprived rats (WD) was examined by micropuncture. The micropuncture measurements and collections were obtained 90 and 120 min after induction of anesthesia, and completed within $30 \mathrm{~min}$. These measurements and collections were repeated $\sim 70 \mathrm{~min}$ later, which was a timing similar to the third study period in group 2-4 animals.

Group 2 (eight Munich-Wistar rats): In WD of group 2, the effect of AVP inhibition after AII blockade was studied. Baseline micropuncture measurements and collections were performed as in the first 
Table I. Summary of Individual Protocols for Group 1-9 Experimental Animals

\begin{tabular}{|c|c|c|c|c|}
\hline & Fluid intake before study & First study period & Second study period & Third study period \\
\hline $\begin{array}{l}\text { Group } 1 \\
\text { (7 MW rats) }\end{array}$ & $24-48-\mathrm{H}$ water deprivation & No treatment & - & No treatment \\
\hline $\begin{array}{l}\text { Group } 2 \\
\text { (8 MW rats) }\end{array}$ & 24-48-H water deprivation & No treatment & Saralasin & $\begin{array}{l}\text { Saralasin } \\
\quad+d\left(\mathrm{CH}_{2}\right)_{5} \operatorname{Tyr}(\mathrm{Me}) \mathrm{AVP}\end{array}$ \\
\hline $\begin{array}{l}\text { Group } 3 \\
\quad \text { (6 MW rats) }\end{array}$ & $24-48-\mathrm{H}$ water deprivation & No treatment & $d\left(\mathrm{CH}_{2}\right)_{5} \mathrm{Tyr}(\mathrm{Me}) \mathrm{AVP}$ & $\begin{array}{l}d\left(\mathrm{CH}_{2}\right)_{s} \mathrm{Tyr}(\mathrm{Me}) \mathrm{AVP} \\
\quad+\text { saralasin }\end{array}$ \\
\hline $\begin{array}{l}\text { Group } 4 \\
\text { (6 MW rats) }\end{array}$ & 24-48-H water deprivation & - & Saralasin & Saralasin + hydralazine \\
\hline $\begin{array}{l}\text { Group } 5 \\
\quad \text { (8 MW rats) }\end{array}$ & Free access to water & No treatment & Saralasin & - \\
\hline $\begin{array}{l}\text { Group } 6 \\
\quad \text { (6 SD rats) }\end{array}$ & 24-48-H water deprivation & Teprotide & $\begin{array}{l}\text { Teprotide } \\
\quad+d\left(\mathrm{CH}_{2}\right)_{5} \operatorname{Tyr}(\mathrm{Me}) \mathrm{AVP}\end{array}$ & - \\
\hline $\begin{array}{l}\text { Group } 7 \\
\quad \text { (7 SD rats) }\end{array}$ & 24-48-H water deprivation & Indomethacin + teprotide & $\begin{array}{l}\text { Indomethacin + teprotide } \\
\quad+d\left(\mathrm{CH}_{2}\right)_{5} \operatorname{Tyr}(\mathrm{Me}) \mathrm{AVP}\end{array}$ & - \\
\hline $\begin{array}{l}\text { Group } 8 \\
\text { (6 SD rats) }\end{array}$ & Free access to water & No treatment & AVP & - \\
\hline $\begin{array}{l}\text { Group } 9 \\
\quad \text { (6 SD rats) }\end{array}$ & Free access to water & Indomethacin & Indomethacin + AVP & - \\
\hline
\end{tabular}

Dosages employed are $0.3 \mathrm{mg} / \mathrm{kg}$ per h (saralasin), $20 \mu \mathrm{g}\left(d\left[\mathrm{CH}_{2}\right]_{5} \mathrm{Tyr}[\mathrm{Me}] \mathrm{AVP}\right), 0.05 \mathrm{mg}$ (hydralazine), $4 \mathrm{mU} / \mathrm{kg}$ per min (AVP), $6 \mathrm{mg} / \mathrm{kg} \mathrm{per}$ $\mathrm{h}$ (teprotide), and $2 \mathrm{mg} / \mathrm{kg}$ (indomethacin, group 7) and $2 \mathrm{mg} / \mathrm{kg}+2 \mathrm{mg} / \mathrm{kg}$ per h (indomethacin, group 9). Munich-Wistar and SpragueDawley rats are abbreviated as MW and SD rats, respectively.

period of group 1 animals. At the end of this first study period, an intravenous infusion of saralasin $(0.3 \mathrm{mg} / \mathrm{kg}$ per $\mathrm{h})$, an AII antagonist, was started and continued throughout the rest of the experiment. After a 40-min equilibration period, measurement of the SNGFR and its determinants was repeated. Immediately after completion of this second study period, each rat received a $20-\mu \mathrm{g}$ i.v. bolus injection of a long acting specific vasopressin vascular antagonist (7), [1-( $\beta$-mercapto$\beta, \beta$-cyclopentamethylenepropionic acid) 2-(o-methyl) tyrosine] AVP, or $d\left(\mathrm{CH}_{2}\right)_{5} \mathrm{Tyr}(\mathrm{Me}) \mathrm{AVP}$, and micropuncture measurements and collections were again repeated in the subsequent $30 \mathrm{~min}$

Group 3 (six Munich-Wistar rats): In group 3 WD, we first studied the effect of $d\left(\mathrm{CH}_{2}\right)_{5}$ Tyr(Me)AVP alone, followed by the addition of saralasin in the third study period. In these rats, the first study period was carried out as in group 2 . Subsequently, $d\left(\mathrm{CH}_{2}\right)_{5} \mathrm{Tyr}(\mathrm{Me}) \mathrm{AVP}$ was injected as in the third study period of group $2.20 \mathrm{~min}$ later, micropuncture was repeated during the next $30 \mathrm{~min}$. Immediately after this second study period, infusion of saralasin was begun at a rate identical to group 2. After a 40-min equilibration period, measurements and collections again were performed and completed in 30 min (third study period).

Group 4 (six Munich-Wistar rats): In this group of WD, the effect of a nonspecific vasodilator on renal microcirculatory hemodynamics was compared with the effect of AVP antagonist-induced vasodilation (group 2). In this group of animals, the time course described for group 2 was duplicated, except that hydralazine $(0.05 \mathrm{mg}$ i.v.) was substituted for the AVP antagonist, and that measurements and collections before saralasin infusion were omitted.

Group 5 (eight Munich-Wistar rats): In order to identify the specificity of endogenous AII action in WD animals, the effect of saralasin on the systemic and renal cortical circulations was examined in eight Munich-Wistar rats allowed free access to tap water until the time of the study. In these rats, the protocol for the first and second study periods of group 2 animals was duplicated.
Group 6 (six Sprague-Dawley rats): In these WD, the effect of AVP antagonism in the presence of renin-angiotensin inhibition was studied. An intravenous infusion of teprotide $(6 \mathrm{mg} / \mathrm{kg}$ per h), an angiotensin I converting enzyme inhibitor, was started immediately after induction of anesthesia, and continued throughout the duration of the experiment. Measurement of $\overline{\mathrm{AP}}, \mathrm{CO}$, and $\mathrm{RBF}$ was begun $\sim 90$ min after surgical preparation, and completed within $15 \mathrm{~min}$. At the end of this first study period, rats received 20- $\mu \mathrm{g}$ i.v. bolus injection of $d\left(\mathrm{CH}_{2}\right)_{5}$ Tyr(Me)AVP. $20 \mathrm{~min}$ after injection of the AVP antagonist, measurement of $\overline{\mathrm{AP}}, \mathrm{CO}$, and $\mathrm{RBF}$ was repeated (second study period).

Group 7 (seven Sprague-Dawley rats): Seven additional WD were used to examine the effect of prostaglandin inhibition on the AVP antagonist-induced changes in $\overline{\mathrm{AP}}, \mathrm{CO}$, and $\mathrm{RBF}$. In this group, the protocol described for group 6 was duplicated except that, in addition to continuous teprotide infusion, group 7 rats received a $2-\mathrm{mg} / \mathrm{kg}$ i.v. injection of indomethacin at the start of surgical preparation.

Group 8 (six Sprague-Dawley rats): In these water-diuretic rats, the effect of a moderately pressor dose of exogenous vasopressin on systemic and renal circulatory dynamics was examined. In order to achieve hyposthenuria and suppress endogenous AVP release, the rats were given a continuous hypotonic fluid infusion. Immediately after restoration of the surgical plasma loss, an intravenous infusion $(0.83 \%$ dextrose, $0.3 \% \mathrm{NaCl}$ ) was started at a rate of $60 \mathrm{ml} / \mathrm{kg}$ per $\mathrm{h}$. We previously found this regimen to effectively maintain urine hypotonicity (osmolality below $170 \mathrm{mosmol} / \mathrm{kg}$ or specific gravity below 1.005) without significantly changing the serum level of glucose (8). Approximately $2 \mathrm{~h}$ after surgical preparation, measurements of $\overline{\mathrm{AP}}, \mathrm{CO}$, and $\mathrm{RBF}$ were begun and completed within $15 \mathrm{~min}$. At the end of this first study period, a continuous intravenous infusion of AVP $(4 \mathrm{mU} /$ kg per min, Pitressin, Parke, Davis \& Co., Detroit, MI) was started. 5 min later, after a steady state was reached for $\overline{\mathrm{AP}}$, the above-mentioned measurements and collections were again performed within a 15-min interval (second study period). 
Group 9 (six Sprague-Dawley rats): Using additional water-diuretic rats, the influence of prostaglandin inhibition on the vasopressininduced changes in $\overline{\mathrm{AP}}, \mathrm{CO}$, and $\mathrm{RBF}$ was examined. The protocol described for group 8 was duplicated, except that group 9 animals received indomethacin $(2-\mathrm{mg} / \mathrm{kg}$ i.v. bolus at the start of surgical preparation, followed by $2 \mathrm{mg} / \mathrm{kg}$ per h continuous infusion).

Analytical. The volume of fluid collected from individual proximal tubules was estimated from the length of the fluid column in a constant-bore capillary tube of known internal diameter. The concentration of inulin in tubule fluid was measured, usually in duplicate, by the microfluorescence method of Vurek and Pegram (18). Inulin concentration in plasma was determined by the macroanthrone method of Führ et al. (19). $C_{E}$ and $C_{A}$ were determined, usually in duplicate, by the fluorometric method of Viets et al. (20).

Analysis of variance was used to determine statistical significance of differences in groups 1-5. Paired and unpaired $t$ test was used for groups 6-9. Statistical significance was defined as $P<0.05$. Significance values are given at the levels of $<0.05$ and $<0.01$.

\section{Results}

Base-line renal microcirculatory indices, measured in 21 waterdeprived rats (groups 1-3) and 8 nonwater-deprived rats (nonWD) (group 5) are presented in Table II. The body weight of group 1-3 animals averaged $276 \pm 6 \mathrm{~g}$ before water deprivation, which corresponded to a $12 \pm 1 \%$ loss of body weight during the deprivation. At the time of study, therefore, there was a significant difference in body weight between WD and nonWD animals. Mean arterial pressure was comparable in the two groups. Mean glomerular capillary hydraulic pressure, $\overline{\mathbf{P}}_{\mathrm{GC}}$, was significantly elevated after water deprivation, while proximal tubule hydraulic pressure, $\mathrm{P}_{\mathrm{T}}$, was unchanged, leading to a significantly higher value for the mean glomerular transcapillary hydraulic pressure difference, $\overline{\Delta \mathrm{P}}$. Efferent arteriolar hydraulic pressure $\left(P_{E}\right)$ was comparable in the two groups. Hemoconcentration after water deprivation was reflected by a significant elevation in plasma protein concentration, $C_{A}$, and hence systemic plasma oncotic pressure, $\pi_{A}$, as well as an increase in hematocrit. Both SNGFR and $Q_{A}$ were decreased to a similar extent $(\sim 50 \%)$ after water deprivation, leading to near-constancy in SNFF. The marked decrease in SNGFR was, therefore, attributed largely to the marked decrease in $Q_{A}$ and a simultaneously observed marked decrease in the ultrafiltration coefficient, $K_{\mathrm{f}}$, as well as, but to a lesser extent, the increase in systemic plasma oncotic pressure, $\pi_{\mathrm{A}}$. These changes were partly offset by the increase in $\overline{\Delta \mathrm{P}}$, the latter tending to prevent an even greater reduction in SNGFR. The decrease in $Q_{A}$, in turn, was attributed largely to a marked increase in $R_{A}$ and $R_{E}$. The increase in $R_{E}$ was proportionately more marked than $R_{A}$, thus accounting for the observed increase in $\bar{P}_{G C}$.

In the absence of pharmacologic intervention (group 1 rats), all hemodynamic and renal microcirculatory indices remained essentially unchanged with time, as shown in Table III.

Administration of saralasin in the second period to group 2 water-deprived rats led only to a slight decrease in $\overline{\mathrm{AP}}$, on average by $6 \mathrm{mmHg}$ (Table III). Saralasin treatment induced profound changes in several renal microcirculatory parameters: $\overline{\mathbf{P}}_{\mathrm{GC}}$ decreased while $\mathrm{P}_{\mathrm{T}}$ remained unchanged, leading to a fall in $\overline{\Delta \bar{P}} \cdot C_{A}$ and $\pi_{A}$ were unaffected by angiotensin II inhibition, while both $C_{E}$ and $\pi_{E}$ decreased. A dramatic increase in $\mathbf{Q}_{A}$ was observed; its value doubled after saralasin infusion. SNGFR also increased by $11 \mathrm{nl} / \mathrm{min}$. The relatively greater increase in $Q_{A}$ than SNGFR was reflected by a fall in SNFF. It is clear from Table III that the increase in $Q_{A}$ was the consequence of a profound fall in both $R_{A}$ and $R_{E}$. The decrease in $R_{A}$ was proportionately less than the decrease in $R_{E}$, which accounted for the observed decrease in $\overline{\mathbf{P}}_{\mathrm{GC}}$ during saralasin infusion. In addition to the increase in $\mathrm{Q}_{\mathrm{A}}, K_{\mathrm{f}}$ was found to markedly increase. Overall, saralasin treatment tended to partially correct the abnormalities seen during water deprivation by modulating the levels of $K_{f}, R_{A}$, and $R_{E}$.

After pretreatment with saralasin, administration of the AVP antagonist $d\left(\mathrm{CH}_{2}\right)_{5} \mathrm{Tyr}(\mathrm{Me}) \mathrm{AVP}$ to group 2 water-deprived rats led to a substantial reduction in $\overline{\mathrm{AP}}$, on average by 22 mmHg (Table III). Both $\overline{\mathbf{P}}_{\mathrm{GC}}$ and $\overline{\Delta \mathbf{P}}$ decreased, while $\mathrm{P}_{\mathrm{T}}$ remained constant. $C_{A}$ and $\pi_{A}$ remained unchanged, while both $C_{E}$ and $\pi_{E}$ decreased. Marked reductions occurred in $Q_{A}$ as well as SNGFR, the latter primarily due to the decreases in $\mathrm{Q}_{\mathrm{A}}$ and $\overline{\Delta \mathrm{P}}$, since values for $K_{\mathrm{f}}$ and $\mathrm{C}_{\mathrm{A}}$ were essentially unaffected, as shown. Contrasting to treatment with saralasin alone, afferent arteriolar resistance was unchanged after $d\left(\mathrm{CH}_{2}\right)_{5} \mathrm{Tyr}(\mathrm{Me}) \mathrm{AVP}$ addition, and $\mathrm{R}_{\mathrm{E}}$ increased slightly.

When $d\left(\mathrm{CH}_{2}\right)_{5} \mathrm{Tyr}(\mathrm{Me}) \mathrm{AVP}$, a specific vascular antagonist, was given without simultaneous inhibition of AII (group 3, second period), the systemic hemodynamic and renal microcirculatory parameters were only minimally affected. Thus, the AVP antagonist exerted only a mild depressor effect on systemic circulation, as indicated by an average fall of $\overline{\mathrm{AP}}$ of $7 \mathrm{mmHg}$, and was without effect on $\mathbf{R}_{\mathrm{A}}, \mathbf{R}_{\mathrm{E}}$, and $K_{\mathrm{f}}$. Additional

Table II. Summary of Renal Cortical Microcirculatory Indices Measured Under Basal Conditions in WD and Non-WD Rats

\begin{tabular}{|c|c|c|c|c|c|c|c|c|c|c|c|c|c|c|c|c|c|}
\hline & BW & $\overline{\mathbf{A P}}$ & $\overline{\mathbf{P}}_{\mathbf{O C}}$ & $\mathbf{P}_{\mathbf{T}}$ & $\overline{\Delta \mathbf{P}}$ & $\mathbf{P}_{\mathbf{E}}$ & $\mathbf{C}_{\boldsymbol{A}}$ & $\mathbf{C}_{\mathrm{E}}$ & $\boldsymbol{\Pi}_{\boldsymbol{A}}$ & $\Pi_{E}$ & SNFF & SNGFR & $Q_{A}$ & $\mathbf{R}_{\mathbf{A}}$ & $\mathbf{R}_{\mathbf{E}}$ & $K_{\mathbf{f}}$ & $\begin{array}{l}\text { Het } \\
\text { (vol) }\end{array}$ \\
\hline & $g$ & $\mathrm{mmHg}$ & $m m H g$ & $m m H g$ & $\mathrm{mmHg}$ & $\mathrm{mmHg}$ & $g / d l$ & $g / d l$ & $\mathrm{mmHg}$ & $\mathrm{mmHg}$ & & $n l / \min n$ & $l / \min$ & $\times 10^{10} \mathrm{dyn}$. & $s \cdot \mathrm{cm}^{-5} \mathrm{nl}$ & $/(s \cdot m m H g)$ & $\%$ \\
\hline \multicolumn{18}{|l|}{ WD rats } \\
\hline$(n=21)$ & 238 & 109 & 64 & 14 & 50 & 19 & 6.8 & 9.7 & 25 & 47 & 0.32 & 23.2 & 71 & 2.43 & 2.90 & 0.028 & 55.5 \\
\hline (士) & 3 & 2 & 1 & 1 & 1 & 1 & 0.1 & 0.4 & 1 & 2 & 0.01 & 1.3 & 5 & 0.20 & 0.24 & 0.003 & 0.4 \\
\hline \multicolumn{18}{|c|}{ Non-WD rats } \\
\hline$(n=8)$ & 264 & 111 & 48 & 12 & 36 & 18 & 5.8 & 8.1 & 19 & 32 & 0.28 & 44.8 & 169 & 1.68 & 0.97 & 0.087 & 48.2 \\
\hline$( \pm)$ & 8 & 2 & 2 & 1 & 2 & 1 & 0.1 & 0.2 & 1 & 1 & 0.02 & 4.1 & 23 & 0.18 & 0.14 & 0.011 & 1.0 \\
\hline$P$ value* & $<0.01$ & NS & $<0.01$ & NS & $<0.01$ & NS & $<0.01$ & $<0.01$ & $<0.01$ & $<0.01$ & NS & $<0.01$ & $<0.01$ & $1<0.05$ & $<0.01$ & $<0.01$ & $<0.01$ \\
\hline
\end{tabular}

Values are expressed as mean \pm 1 SE. Minimum $K_{f}$ values were calculated when filtration pressure equilibrium was reached (i.e., $\Pi_{E} \simeq \overline{\Delta P}$ ). Unique $K_{f}$ values were calculated when filtration pressure equilibrium was not reached (i.e., $\Pi_{\mathrm{E}}<\overline{\Delta \mathrm{P}}$ ). To calculate mean $K_{\mathrm{f}}$ values, unique $K_{\mathrm{f}}$ values (14 in WD and 6 in non-WD rats) were pooled within each group. * Calculated using variance analysis. NS denotes $P>0.05$. 


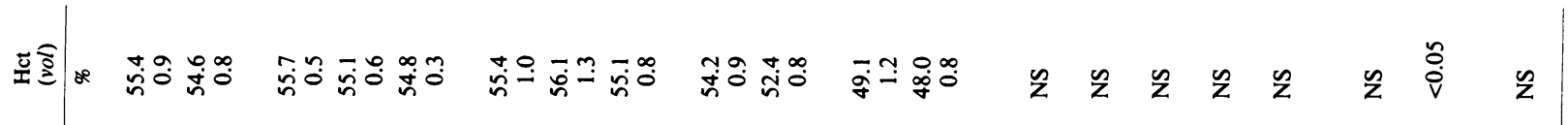

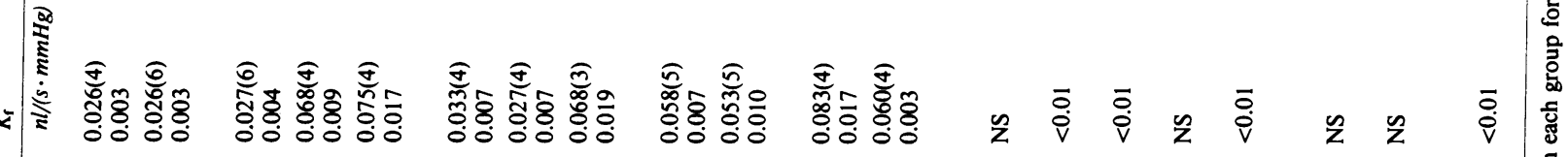

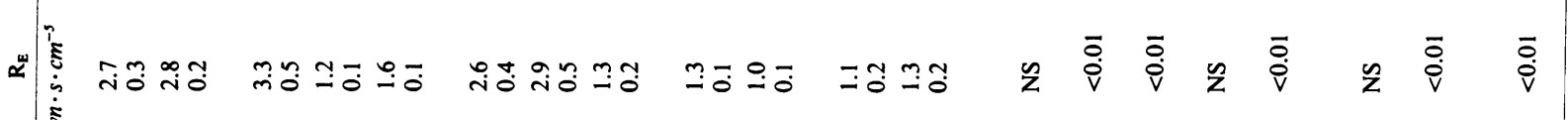
๙

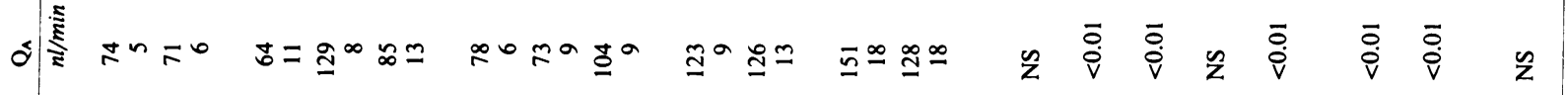

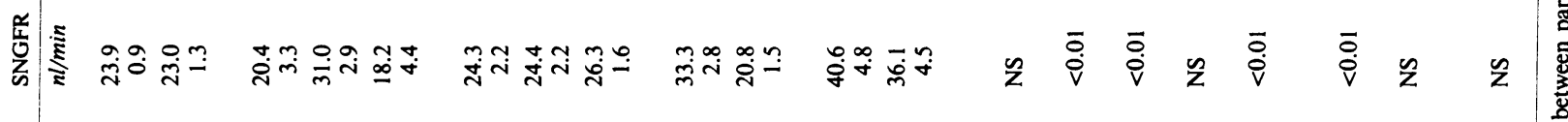

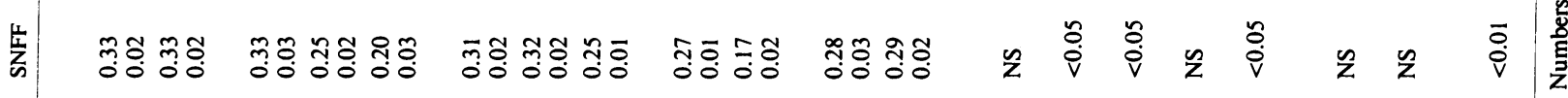

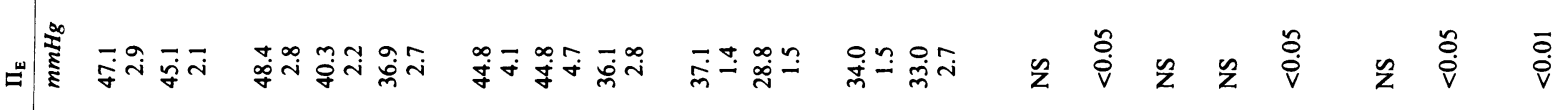

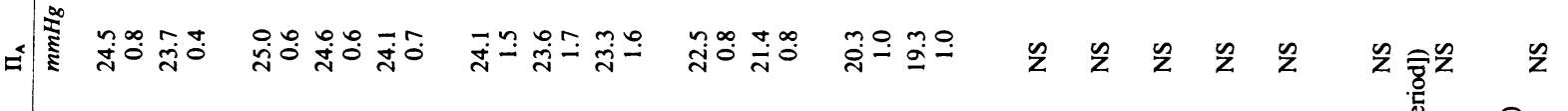

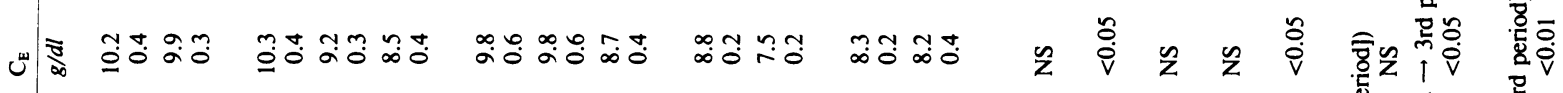

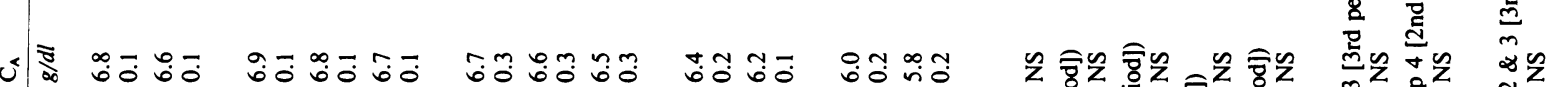

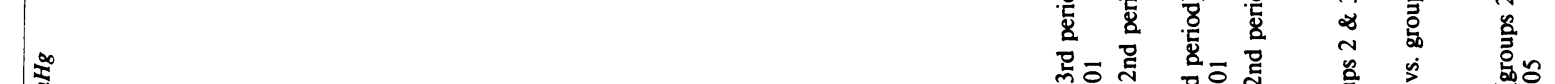
凹)

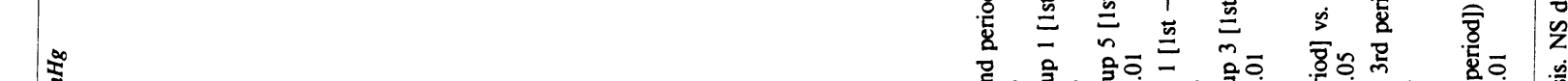

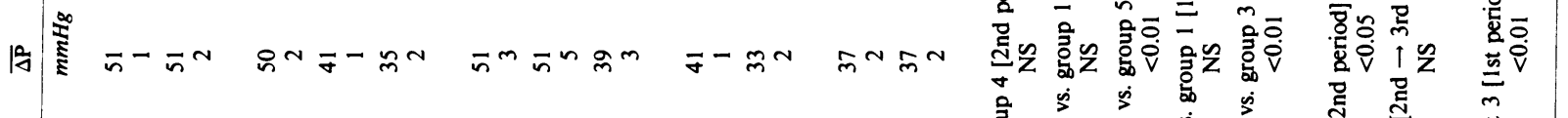
\& $g$ 然

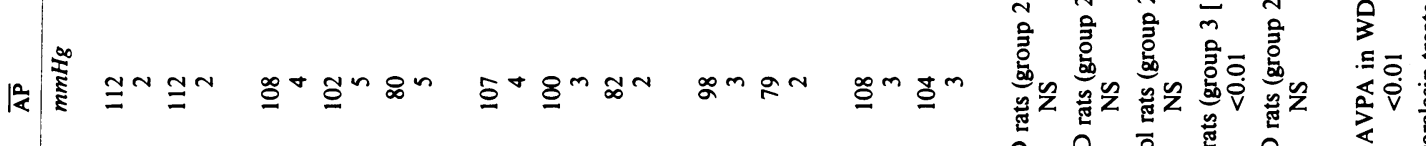

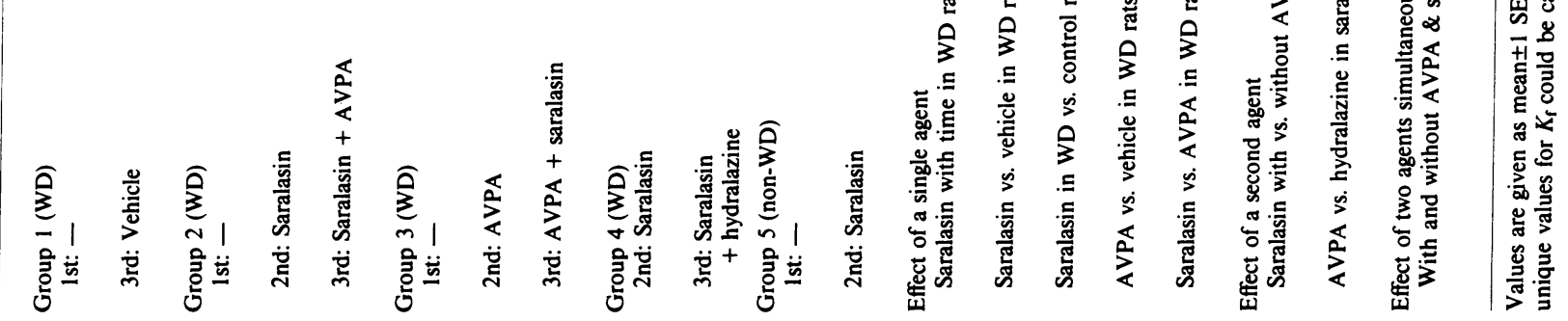




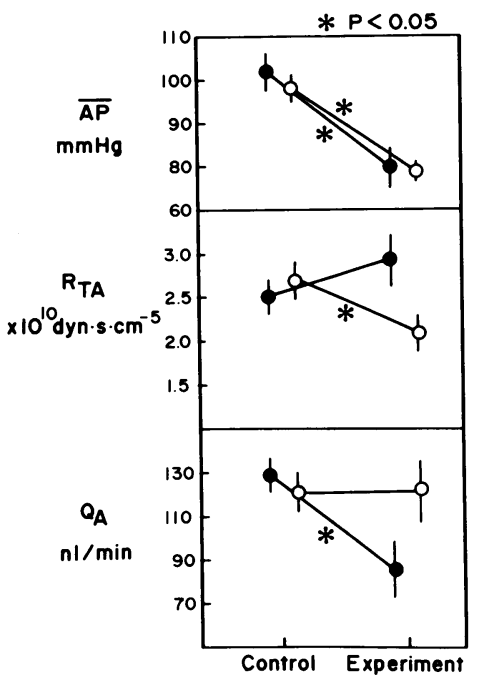

Figure 1. Summary of changes in mean systemic arterial pressure, total renal arteriolar resistances $\left(\mathbf{R}_{\mathrm{TA}}\right)$, and $Q_{A}$ in response to administration of $d\left(\mathrm{CH}_{2}\right)_{5}$ Tyr(Me)AVP (group 2) or hydralazine (group 4) in saralasintreated WD. Values are expressed as mean $\pm 1 \mathrm{SE}$.

-, AVP antagonist $(n=8)$; $\circ$, hydralazine $(n=6)$.

inhibition of AII in these water-deprived rats pretreated with the AVP antagonist (Table III, group 3, third period) led to a decrease in $\overline{\mathrm{AP}}$ by $\sim 20 \mathrm{mmHg}$, which indicated that antagonism of both AVP and AII causes dramatic reduction in $\overline{\mathrm{AP}}$, which is not achieved through inhibition of either vasopressor hormone alone. As in group $2, \overline{\mathrm{P}}_{\mathrm{GC}}$ decreased while $\mathrm{P}_{\mathrm{T}}$ remained constant, so that $\overline{\Delta P}$ fell. $C_{A}$ and $\pi_{A}$ again remained unchanged, while both $C_{E}$ and $\pi_{E}$ decreased. The near-constancy of SNGFR was due to the opposing influences of increases in $\mathrm{Q}_{\mathrm{A}}$ and $K_{\mathrm{f}}$, and a decrease in $\overline{\Delta \mathrm{P}}$.

The effects of AVP inhibition were compared with those resulting from administration of a systemically equivasodepressor dose of hydralazine in rats also pretreated with saralasin (group 4, third period). Administration of hydralazine resulted in a substantial decrease in $\overline{\mathrm{AP}}$, on average by $\sim 20 \mathrm{mmHg}$. Values for $\overline{\mathrm{P}}_{\mathrm{GC}}$ and $\overline{\Delta \mathrm{P}}$ decreased as well, leading to a decrease in SNGFR by $\sim 40 \%$. $C_{A}$ decreased slightly, and values for both $\mathrm{Q}_{\mathrm{A}}$ and $K_{\mathrm{f}}$ remained essentially unchanged (Table III and Fig. 1). Both $R_{A}$ and $R_{E}$ decreased to a mild but significant extent. This dilation of the afferent and efferent arterioles served to maintain $Q_{A}$ in the face of systemic vasodilation, the latter evidenced by the profound fall in $\overline{\mathrm{AP}}$. Overall, the decline in SNGFR was primarily due to the marked fall in $\overline{\mathbf{P}}_{\mathrm{GC}}$. In contrast to the changes seen in group $2 \mathrm{WD}$ animals, saralasin treatment was essentially without effect in group 5 rats having had free access to water, as shown in Table III.

The effect of AVP inhibition on systemic and whole kidney circulatory dynamics was studied in WD pretreated with an angiotensin-converting enzyme inhibitor, teprotide (group 6) (Table IV, Fig. 2). Injection of $d\left(\mathrm{CH}_{2}\right)_{5} \mathrm{Tyr}(\mathrm{Me}) \mathrm{AVP}$ induced a significant decrease in $\overline{\mathrm{AP}}$ by $\sim 30 \mathrm{mmHg}$ without a significant change in cardiac output, so that calculated SVR significantly decreased. Renal blood flow, on the other hand, decreased significantly, on average by $0.9 \mathrm{ml} / \mathrm{min}$, while RVR remained unchanged. Thus, during AVP antagonism, the renal fraction of cardiac output (RBF/CO ratio), or the ratio of SVR/RVR, significantly decreased, from $0.100 \pm 0.013$ to $0.074 \pm 0.015$ $(P<0.05)$ (Table IV, Fig. 2).

The effect of AVP inhibition was also studied in WD with indomethacin in addition to teprotide (group 7) (Table IV,

Table IV. Summary of Hemodynamic Data for Group 6-9 Animals

\begin{tabular}{|c|c|c|c|c|c|c|c|c|}
\hline & $\overline{\mathbf{A P}}$ & HR & $\mathrm{U}_{\mathrm{SG}}$ & $\mathrm{CO}$ & RBF & SVR & RVR & $\begin{array}{l}\text { SVR/RVR } \\
\text { (RBF/CO) }\end{array}$ \\
\hline & $m m H g$ & per min & & $\mathrm{ml} / \mathrm{min}$ & $\mathrm{ml} / \mathrm{min}$ & \multicolumn{2}{|c|}{$\mathrm{mmHg} /(\mathrm{ml} / \mathrm{min})$} & \\
\hline \multicolumn{9}{|c|}{ Group $6(n=6)$} \\
\hline Pre-AVPA & $112 \pm 5$ & - & - & $51 \pm 3$ & $4.9 \pm 0.5$ & $2.3 \pm 0.2$ & $25.2 \pm 2.8$ & $0.100 \pm 0.013$ \\
\hline Post-AVPA & $80 \pm 10$ & & & $62 \pm 9$ & $4.0 \pm 0.5$ & $1.4 \pm 0.2$ & $23.6 \pm 4.6$ & $0.074 \pm 0.015$ \\
\hline \multicolumn{9}{|c|}{ Group $7(n=7)$} \\
\hline Pre-AVPA & $106 \pm 5$ & - & - & $62 \pm 9$ & $4.8 \pm 0.4$ & $1.9 \pm 0.3$ & $22.6 \pm 2.9$ & $0.084 \pm 0.011$ \\
\hline Post-AVPA & $84 \pm 6$ & & & $58 \pm 8$ & $4.8 \pm 0.3$ & $1.7 \pm 0.3$ & $17.0 \pm 1.0$ & $0.092 \pm 0.016$ \\
\hline$P^{*}$ & $<0.01$ & & & NS & NS & $<0.05$ & $<0.05$ & NS \\
\hline$P \nsucceq$ & NS & - & - & NS & $<0.05$ & $<0.05$ & NS & $<0.05$ \\
\hline \multicolumn{9}{|c|}{ Group $8(n=6)$} \\
\hline Post-AVP & $137 \pm 9$ & $382 \pm 20$ & $1.012 \pm 0.001$ & $98 \pm 9$ & $9.6 \pm 1.3$ & $1.4 \pm 0.1$ & $17.3 \pm 1.9$ & $0.106 \pm 0.019$ \\
\hline$P^{*}$ & $<0.01$ & NS & $<0.01$ & $<0.01$ & $<0.01$ & $<0.01$ & $<0.05$ & $<0.01$ \\
\hline \multicolumn{9}{|c|}{ Group $9(n=6)$} \\
\hline Pre-AVP & $115 \pm 4$ & $385 \pm 21$ & $1.003 \pm 0.000$ & $103 \pm 5$ & $9.3 \pm 0.8$ & $1.1 \pm 0.1$ & $12.7 \pm 0.9$ & $0.090 \pm 0.005$ \\
\hline Post-AVP & $135 \pm 6$ & $380 \pm 20$ & $1.012 \pm 0.001$ & $95 \pm 6$ & $8.3 \pm 0.7$ & $1.4 \pm 0.1$ & $16.8 \pm 1.3$ & $0.088 \pm 0.008$ \\
\hline$P^{*}$ & $<0.01$ & NS & $<0.01$ & NS & $<0.05$ & $<0.05$ & $<0.05$ & NS \\
\hline$P \S$ & NS & NS & NS & NS & $<0.05$ & NS & NS & $<0.05$ \\
\hline
\end{tabular}

Values are given as mean \pm 1 SE. HR, heart rate; $U_{S G}$, urine specific gravity. * Paired $t$ test comparing absolute values for the two periods within the same group. ¥ Unpaired $t$ test comparing the changes between the two periods for group 6 vs. group 7 . $\S$ Unpaired $t$ test comparing the changes between the two periods for group 8 vs. group 9. 

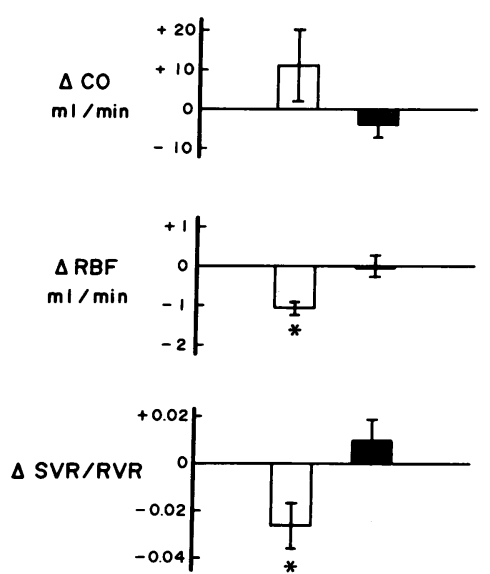

Figure 2. Summary of changes in CO, RBF, and RBF/CO (or SVR/ $\mathrm{RVR}$ ) in response to $d\left(\mathrm{CH}_{2}\right)_{5} \mathrm{Tyr}(\mathrm{Me}) \mathrm{AVP}$ administration in teprotide-treated WD. Animals were pretreated with either indomethacin (group 7, shaded bars) or vehicle (group 6, open bars). * indicates statistical significance of the changes seen, in each group, within the same animals. When comparison was made between changes in group 8 vs. group 9 animals, $\triangle R B F$ and $\triangle R B F / C O$ were statistically different.

Fig. 2). In these rats, base-line $\overline{\mathrm{AP}}$ and $\mathrm{RBF} / \mathrm{CO}$ ratio tended to be lower and $\mathrm{CO}$ higher than in nonindomethacin-treated rats; however, the differences in these values did not reach statistical significance. After administration of AVP antagonist, a significant decrease in $\overline{\mathrm{AP}}$ was again observed, on average by $\sim 20 \mathrm{mmHg}$, without a significant change in cardiac output, so that SVR significantly decreased. However, in contrast to the pattern seen in group 6 rats, RVR significantly decreased, so that both RBF and RBF/CO ratio remained unchanged.

The effect of exogenous AVP was studied in water-loaded rats (i.e., suppressed endogenous release of the hormone) (group 8) (Table IV, Fig. 3). In these animals, the administration of AVP led to a significant increase in $\overline{\mathrm{AP}}$, on average by $\sim 20$ $\mathrm{mmHg}$. Cardiac output significantly decreased in association with an increase in SVR. RBF, on the other hand, increased, on average by $0.8 \mathrm{ml} / \mathrm{min}$, despite an increase in RVR. The increase in RBF was due to a proportionately lesser AVPinduced increase in renal as compared with systemic vascular resistance, since $R B F / C O$ or $S V R / R V R$ ratio increased significantly, on average from $0.083 \pm 0.014$ to $0.106 \pm 0.019$ ( $P$ $<0.01$ ).

In a separate group of water-diuretic rats, AVP was administered while potential stimulation of prostaglandin release by AVP was blocked by pretreating the animals with indomethacin (group 9) (Table IV, Fig. 3). In these animals, base-line hemodynamic parameters were not significantly different from those of group 8 animals (Table IV). Administration of AVP induced an increase in $\overline{\mathrm{AP}}$, on average by $\sim 20 \mathrm{mmHg}$, a magnitude similar to that seen in group 8 animals. Both SVR and RVR increased. However, in contrast to group 8 animals, AVP induced a comparable increase in both SVR and RVR in these group 9 indomethacin-pretreated animals, so that $\mathrm{RBF} / \mathrm{CO}$ or SVR/RVR ratio remained essentially unchanged. In association with a uniform (though statistically insignificant) reduction in $\mathrm{CO}, \mathrm{RBF}$ significantly fell by $1.0 \mathrm{ml} / \mathrm{min}$.
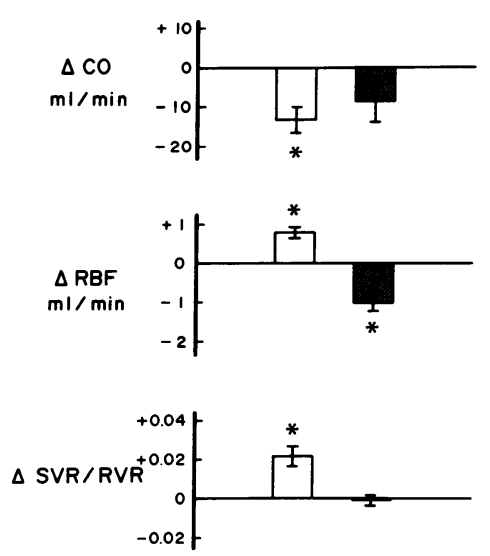

Figure 3. Summary of changes in CO, RBF, and RBF/CO (or SVR/ RVR) in response to a moderately pressor dose of AVP (4 mU/kg per min) in water-diuretic rats. Animals were pretreated with either indomethacin (group 9, shaded bars) or vehicle alone (group 8, open bars). * indicates statistical significance for the changes seen, in each group, within each animal. When comparison was made between changes in group 8 vs. group 9 animals, both $\triangle R B F$ and $\triangle R B F / C O$ were statistically different.

\section{Discussion}

Filtration rate of superficial nephrons during water deprivation was found to be markedly depressed, almost to half the value of control animals. Contributing to the decrease in SNGFR during water deprivation were low levels of $Q_{A}(\sim 50 \%$ of normal controls) and $K_{\mathrm{f}}(\sim 30 \%$ of normal controls), as well as $1 \mathrm{~g} / \mathrm{dl}$ increase in systemic plasma protein concentration (Table II). A qualitatively similar pattern was previously reported in chronic forms of ECF volume depletion $(21,22)$, with the difference that systemic plasma protein concentration, hence $\pi_{\mathrm{A}}$, was normal in the chronically volume-contracted state. On the other hand, the glomerular capillary hydraulic pressure, and hence the transcapillary hydraulic pressure difference, were elevated in water-deprived rats, on average by some $15 \mathrm{mmHg}$ above the control levels. This rise in $\overline{\Delta \mathrm{P}}$ partially offset the changes in the other three determinants and tended to preserve SNGFR.

The relative contribution of each determinant to the low value of SNGFR in WD animals was evaluated. Theoretical values of SNGFR were computed after substituting, successively, a normal value for each of the four determinants of SNGFR, while using the other three values obtained during water deprivation. These predicted values of SNGFR are given in Table $V$. Not surprisingly, substituting a normal value for $\overline{\Delta \mathbf{P}}$ yields a SNGFR value even lower than actually obtained in the WD experimental animals. Substituting normal values for either $C_{A}, Q_{A}$, or $K_{f}$ partially restores SNGFR. None of these individual substitutions, however, results in a SNGFR value approaching $44.8 \mathrm{nl} / \mathrm{min}$, as measured in non-WD control animals.

Although selective changes in either $\mathrm{Q}_{\mathrm{A}}$ or $K_{\mathrm{f}}$ alone appear to have only minor influence on SNGFR, a dramatic improvement in SNGFR is predicted should both of these determinants be concurrently normalized. Thus, by using the values of $\mathrm{Q}_{\mathrm{A}}$ and $K_{\mathrm{f}}$ measured in non-WD, and those of $\overline{\Delta P}$ and $C_{A}$ from 
Table V. Theoretical Effect of Selective Normalization of Determinants for SNGFR on SNGFR Value

\begin{tabular}{ll}
$\begin{array}{l}\text { Determinant selectively normalized } \\
\text { in water-deprived condition }\end{array}$ & $\begin{array}{l}\text { Predicted SNGFR } \\
\text { value }\end{array}$ \\
\hline & $n l /$ min \\
$\overline{\Delta \mathbf{P}}$ & 10.9 \\
$\mathrm{C}_{\mathrm{A}}$ & 28.3 \\
$\mathrm{Q}_{\mathrm{A}}$ & 31.2 \\
$K_{\mathrm{f}}$ & 25.2 \\
$K_{\mathrm{f}}$ and $\mathrm{Q}_{\mathrm{A}}$ & 57.8
\end{tabular}

WD, SNGFR is calculated to be $57.8 \mathrm{nl} / \mathrm{min}$, a value even higher than that measured in control animals. This synergistic effect of $\mathrm{Q}_{\mathrm{A}}$ and $K_{\mathrm{f}}$ on SNGFR relates to the hydrodynamic character of glomerular filtration in both normal and WD. That is, due to attainment of near-filtration pressure equilibrium at the distal-most end of the glomerular capillary, an increase in $K_{\mathrm{f}}$ alone (by merely shifting the equilibrium point toward the afferent arteriole along the glomerular capillary) has little influence on SNGFR, just as a marked rise in $\mathrm{Q}_{\mathrm{A}}$ alone (by achieving a profound filtration pressure disequilibrium) also fails to raise SNGFR substantially. By contrast, when simultaneous changes occur in both of these terms, an increase in $K_{\mathrm{f}}$ will allow SNGFR to increase linearly when $\mathrm{Q}_{\mathrm{A}}$ increases, without achievement of filtration pressure disequilibrium. An increase in $\mathrm{Q}_{\mathrm{A}}$, in turn, is expected to allow an increase in $K_{\mathrm{f}}$ to enhance local transglomerular flux, without having filtration cease by the end of the glomerular capillary. Overall, the markedly low levels of $\mathrm{Q}_{\mathrm{A}}$ and $K_{\mathrm{f}}$ together account, almost entirely, for the observed profound depression of SNGFR in WD animals. Nevertheless, it should be recognized that, although $Q_{A}$ is markedly low, and contributes to the low SNGFR, both $Q_{A}$ and SNGFR would have been even lower had the circulating level of AVP not been appropriately elevated (see below).

To examine the functional role of the renin-angiotensin system in the markedly altered glomerular microcirculatory dynamics of acutely ECF-depleted animals, the effect of a specific antagonist of AII, saralasin, was studied (group 2). Pharmacological blockade of AII action led to modest reductions in both systemic arterial and glomerular capillary hydraulic pressure, on average by 6 and $9 \mathrm{mmHg}$, respectively. In addition, angiotensin inhibition led to reductions in both afferent and efferent arteriolar resistances. This arteriolar vasodilation was sufficient to cause a significant and marked rise in $Q_{A}$, despite the mild systemic vasodilation. Together with a concurrent rise in the ultrafiltration coefficient, the saralasininduced rise in $Q_{A}$ brought about an increase in SNGFR, even in the face of a marked fall in $\overline{\mathrm{P}}_{\mathrm{GC}}$. Qualitatively similar effects were seen with AII inhibition in volume-depleted animals pretreated with a vasopressin antagonist (group 3). In contrast, saralasin infusion exerted no discernible influence on these parameters in nonvolume-depleted animals (group 5). Thus, the acute form of ECF depletion is characterized by an enhanced vasoconstrictor action of AII on renal arterioles, and presumably glomerular mesangium as well, as indicated by the low level of $K_{\mathrm{f}}$. Hypoperfusion and hypofiltration of glomeruli under this circumstance can therefore be attributed, to a large extent, to the direct constrictor actions of AII on the renal microvasculature. Using saralasin or angiotensin I converting enzyme inhibition, previous investigators demonstrated profound direct renal actions of AII in the chronic forms of ECF volume depletion (21) and other conditions characterized by high levels of endogenous AII (23-26).

Our experiments using a specific AVP antagonist demonstrated that the influence of endogenous AVP on renal hemodynamics is clearly different from the direct renal actions of AII mentioned above. In the present micropuncture studies, inhibition of AVP action was carried out under two circumstances, without (group 3) or with (group 2) concomitant inhibition of AII. When AII action was intact (group 3), administration of a specific AVP antagonist caused mild systemic vasodilation (indicated by a slight fall in $\overline{\mathrm{AP}}$ ). However, no change was detected in renal arteriolar resistances, so that $Q_{A}$ and SNGFR remained essentially constant. When the AVP antagonist was given to AII-inhibited WD (group 2), renal arteriolar resistance again remained unaffected, but a profound systemic vasodilation occurred, which was evidenced by a dramatic fall in $\overline{\mathrm{AP}}$. A similar selective influence of AVP inhibition on systemic blood pressure was also demonstrated in our recent study of two-kidney Goldblatt hypertension (23), another condition characterized by a high circulating level of AVP (10).

In the present experiments, simultaneous assessment of cardiac output and whole kidney blood flow allowed further documentation of this extrarenal specific effect of AVP inhibition. In WD animals (group 6), AVP inhibition indeed decreased only systemic (or extrarenal), but not renal, vascular tone. In keeping with this contention that high circulating level of AVP has a preferential constrictor action on the extrarenal vasculature, Heyndrickx et al. (13), studying conscious dogs, noted that the increase in renal vascular resistance after infusion of a moderately pressor dose of AVP, was less marked than the increase in the resistance of the mesenteric and iliac vascular beds. Similarly, Liard et al. (12) reported that the infusion of AVP to conscious dogs, achieving a serum level within the physiological range, led to a marked decrease in $\mathrm{CO}$ while renal blood flow remained unchanged, which implied an increase in relative renal perfusion. Furthermore, Schmid et al. (11), in their study of anesthetized dogs, noted that a low dose infusion of exogenous AVP led to an increase in the absolute value of renal blood flow rate.

That the selective extrarenal action of endogenously released AVP is crucial for the maintenance of glomerular perfusion and filtration in animals with acute ECF volume depletion is readily appreciable from our additional findings using hydralazine. As depicted in Fig. 1, when this nonselective vasodilator was given to volume-depleted animals (group 4), the resulting fall in $\overline{\mathrm{AP}}$, comparable with that after AVP inhibition, was accompanied by a parallel fall in renal arteriolar resistance, so that glomerular plasma flow rate remained constant. In contrast, when AVP antagonist was administered, no change occurred in renal arteriolar resistance, which resulted in a marked fall in $Q_{A}$. The systemic effect of AVP inhibition to reduce $Q_{A}$ was so profound that a simultaneous tendency for $K_{\mathrm{f}}$ to slightly increase failed to sustain SNGFR. ${ }^{2}$

2. In our previous study in two-kidney Goldblatt hypertension (23), AVP inhibition was shown to raise $K_{f}$ when (but only when) AlI was 
In addition to the renin-angiotensin system and vasopressin, the sympathetic nervous system is known to contribute to maintaining the integrity of systemic circulation. Recently, Paller and Linas (3) have demonstrated in conscious rats that, even when two of these pressor systems are impaired, the level of $\overline{\mathrm{AP}}$ can be sustained as long as the third system remains intact. Of note, however, is the evidence indicating that, under barbiturate anesthesia, the ability of the sympathetic nervous system to adjust $\overline{\mathrm{AP}}$ is grossly compromised $(27,28)$. Indeed, the rise in plasma catecholamines regularly occurring during hemorrhage was found to be markedly blunted in pentobarbitalanesthetized dogs (29). Thus, although we did not measure catecholamine levels, the efficiency of the sympathetic nervous system is likely to have been compromised by Inactin, thereby accounting for the pronounced hypotension observed in our studies after antagonism of AII and AVP in WD animals. ${ }^{3}$

AVP is known to stimulate the release of vasodilatory prostaglandins (31-33). Renal tissues, including glomeruli, are particularly rich in enzymes that participate in the biosynthesis of prostaglandins (34-36). Oliver et al. (37) have recently shown that, in dogs, direct intrarenal arterial administration of AVP augments the renal release of prostglandin $E_{2}$. Moreover, when the animals were pretreated with indomethacin, enhanced renal constriction was noted during exogenous AVP administration. Our results in water diuretic animals (groups 8 and 9) confirm their findings: Thus, when a mildly pressor dose of AVP was injected intravenously to rats undergoing water diuresis (group 8), a significant increase in renal blood flow and in $\mathrm{RBF} / \mathrm{CO}$ ratio was seen. However, when potential AVP-induced prostaglandin release was blocked by the cyclooxygenase inhibitor indomethacin (group 9), RBF decreased and $\mathrm{RBF} / \mathrm{CO}$ was unchanged. These results suggest that, when the intrarenal vasodilatory action of prostaglandins is eliminated, exogenous AVP is equally vasoconstrictive on renal and extrarenal vascular beds. ${ }^{4}$ We postulated that the absence of a renal constrictor action of AVP released endogenously in water deprivation, i.e., under physiological conditions, was similarly a consequence of enhanced release of vasodilatory prostaglandins, induced by AVP, and locally attenuating the direct vasoconstrictor effect of the peptide hormone. Thus, administration of AVP antagonist to WD animals led to systemic hypotension and a marked fall in the renal fraction of cardiac output; pretreatment with indomethacin (group 7) essentially

simultaneously inhibited. In the present study, however, such a rise, if any, could not be appreciated, due to achievement of filtration-pressure equilibrium (i.e., $\overline{\Delta \mathrm{P}} \simeq \Pi_{\mathrm{E}}$ ). This indicates that the $K_{\mathrm{r}}$ raising effect of AVP inhibition, even if it occurred, failed to affect SNGFR, due to the profound systemic effect of AVP inhibition, which brought about the fall in $\mathrm{Q}_{\mathrm{A}}$ and $\overline{\Delta \mathrm{P}}$, and attainment of filtration-pressure equilibrium.

3. It should also be noted that the extent to which the differential effect of AVP on systemic vs. renal vasculature affects the overall RBF, depends on the renal capacity of "pressure" autoregulation, i.e., ability to maintain RBF in the face of changes in $\overline{\mathrm{AP}}$. When this system is compromised, as occurs in ECF volume depletion (30), the systemic effect of AVP to maintain $\overline{\mathrm{AP}}$ becomes a more crucial determinant for the level of RBF.

4. Our observations with indomethacin also imply that the release of AVP-sensitive prostaglandins, at least those having vascular actions, is channeled through receptors occupiable by $d\left(\mathrm{CH}_{2}\right)_{5} \mathrm{Tyr}(\mathrm{Me}) \mathrm{AVP}$, i.e., vascular-type AVP receptors. This notion is supported by recent findings in vitro $(31,38-40)$.

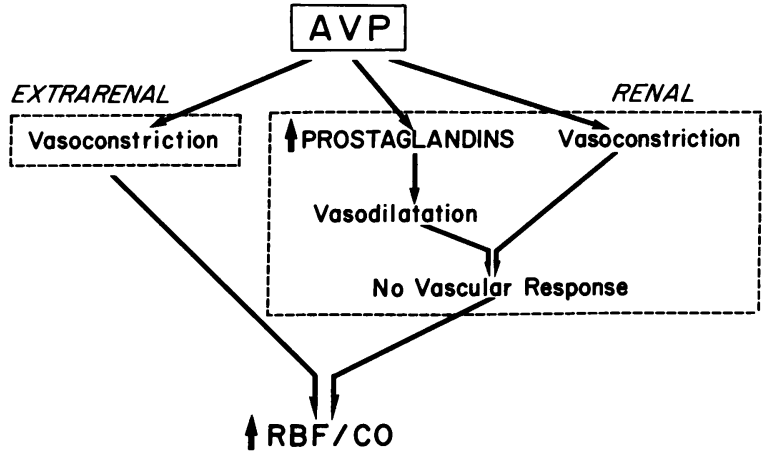

Figure 4. Schematic presentation of the hypothetical mechanism for insensitivity of the renal vasculature to constrictor action of vasopressin (AVP). In this hypothesis, it is proposed, based on the experimental observations, that vasopressin-stimulated local vasodilator actions of prostaglandins are far more prominent in renal than extrarenal vasculature as a whole.

abolished this preferential vasodilatory action of AVP antagonist on the extrarenal vasculature, so that renal blood flow and $\mathrm{RBF} / \mathrm{CO}$ ratio failed to change significantly. Although it is known (41) that AII can similarly induce the release of vasodilatory prostaglandins, our data indicates that the vasoconstrictor action of AII is far more profound than the vasodilatory effect of prostaglandins induced by AII. Thus, pharmacological blockade of AII was found, in our studies, to induce a fall in the renal vascular resistance. In contrast, the vasodilatory effect of prostaglandins released in response to AVP in the dose we used, appears to be sufficient to balance the direct renal vasoconstrictor action of the hormone, resulting, overall, in unchanged renal resistance.

Based on these results, we propose the mechanism for the renal hemodynamic action of AVP shown in Fig. 4: AVP may possess direct constrictor actions on both extrarenal and renal vasculatures. However, due to the release of vasodilatory prostaglandins, the effect of which is to counteract the direct constrictive action of AVP, renal vascular resistance remains unchanged. This scheme also provides an attractive hypothesis for the role of endogenously released AVP. Thus, our results in group 6 and 7 rats point to the notion that the vasodilatory action of AVP-induced prostaglandins, by protecting the kidney from the constrictor action of AVP, is critically important in diverting to the kidney a higher fraction of the cardiac output, the latter being profoundly depressed under conditions of extracellular fluid depletion. ${ }^{5}$

\section{Acknowledgments}

The authors are grateful to Dr. Maurice Manning for the generous gift of $d\left(\mathrm{CH}_{2}\right)_{5} \mathrm{Tyr}(\mathrm{Me}) \mathrm{AVP}$, which made our studies possible. The authors

5. The interaction between AVP and prostaglandin was initially demonstrated for the effect of AVP on hydroosmotic water flow across the terminal nephron (42-43). The sites of this interaction, both receptor and postreceptor levels, have since been suggested (44-48). In view of the paucity of information regarding their interaction on vascular sites, only the interaction at the effector level is presented in our scheme. When the circulating level of AVP becomes extremely high, its direct constrictor action appears to predominate. Indeed, when a markedly pressor dose of AVP was given to dogs, Schmid et al. (11) noted that, not only mesenteric and iliac, but also renal blood flow declined. 
also thank Ms. Mary L. Hughes for technical assistance, and Ms. Janet Stanley for secretarial assistance.

These studies were supported largely by grants from the U. S. Public Health Service (AM-27853 and AM-32160). Dr. V. Kon is a recipient of the American Heart Association Clinician Scientist Award

\section{References}

1. Aisenbrey, G. A., W. A. Handelman, P. Arnold, M. Manning and R. W. Schrier. 1981. Vascular effects of arginine vasopressin during fluid deprivation in the rat. J. Clin. Invest. 67:961-968.

2. Andrews, C. E., Jr., and B. M. Brenner. 1981. Relative contributions of arginine vasopressin and angiotensin II to maintenance of systemic arterial pressure in the anesthetized water-deprived rat. Circ. Res. 48:254-258.

3. Paller, M. S., and S. L. Linas. 1984. Role of angiotensin II, $\alpha$ adrenergic system, and arginine vasopressin on arterial pressure in rats. Am. J. Physiol. 246:H25-H30.

4. Cowley, A. W., Jr., E. W. Quillen, Jr., and M. M. Skelton. 1983. Role of vasopressin in cardiovascular regulation. Fed. Proc. 42:3170 3176.

5. Manning, M., J. Lowbridge, C. T. Stier, Jr., J. Haldar, and W. H. Sawyer. 1977. [1- Deaminopenicillamine, 4-valine]-8-D- arginine vasopressin, a highly potent inhibitor of the vasopressor response to arginine-vasopressin. J. Med. Chem. 20:1228-1230.

6. Lowbridge, J., M. Manning, J. Haldar, and W. H. Sawyer. 1978. [1- ( $\beta$-Mercapto- $\beta, \beta$ - cyclopentamethylenepropionic acid), 4-valine, 8D-arginine] vasopressin, a potent and selective inhibitor of the vasopressor response to arginine-vasopressin. J. Med. Chem. 21:313-315.

7. Kruzynski, M., B. Lammek, M. Manning, J. Seto, J. Haldar, and W. H. Sawyer. 1980. [1- $(\beta$-mercapto- $\beta, \beta$ - cyclopentamethylenepropionic acid), 2- (o-methyl) tyrosine] arginine-vasopressin and [1-( $\beta$ mercapto- $\beta, \beta$-cyclopentamethylenepropionic acid)]arginine-vasopressin, two highly potent antagonists to the vasopressor response to argininevasopressin. J. Med. Chem. 23:364-368.

8. Ichikawa, I., and B. M. Brenner. 1977. Evidence for glomerular actions of ADH and dibutyryl cyclic AMP in the rat. Am. J. Physiol. 233:F102-F117.

9. Ausiello, D. A., J. I. Kreisberg, C. Roy, and M. J. Karnovsky. 1980. Contraction of cultured rat glomerular cells of apparent mesangial origin after stimulation with angiotensin II and arginine vasopressin. J. Clin. Invest. 65:754-760.

10. Möhring, J., B. Möhring, M. Petri, and D. Haack. 1978 Plasma vasopressin concentrations and effects of vasopressin antiserum on blood pressure in rats with malignant two-kidney Goldblatt hypertension. Circ. Res. 42:17-22.

11. Schmid, P. G., F. M. Abboud, M. G. Wendling, E. S. Ramberg, A. L. Mark, D. D. Heistad, and J. W. Eckstein. 1974. Regional vascular effects of vasopressin: plasma levels and circulatory response. Am. J. Physiol. 227:998-1004.

12. Liard, J. F., O. Dériaz, P. Schelling, and M. Thibonnier. 1982. Cardiac output distribution during vasopressin infusion or dehydration in conscious dogs. Am. J. Physiol. 243:H663-H669.

13. Heyndrickx, G. R., D. H. Boettcher, and S. F. Vatner. 1976. Effects of angiotensin, vasopressin, and methoxamine on cardiac function and blood flow distribution in conscious dogs. Am. J. Physiol. 231:1579-1587.

14. Áblad, B. 1963. A study of the mechanism of the hemodynamic effects of hydralazine in man. Acta Pharmacol. Toxicol. 20(Suppl. 1) $1-53$.

15. Ichikawa, I., D. A. Maddox, M. G. Cogan, and B. M. Brenner. 1978. Dynamics of glomerular ultrafiltration in euvolemic MunichWistar rats. Renal Physiol. (Basel) 1:121-131.

16. Deen, W. M., J. L. Troy, C. R. Robertson, and B. M. Brenner 1973. Dynamics of glomerular ultrafiltration in the rat. IV. Determination of the ultrafiltration coefficient. J. Clin. Invest. 52:1500-1508.

17. Arendshorst, W. J., W. F. Finn, and C. W. Gottschalk. 1975.
Autoregulation of blood flow in the rat kidney. Am. J. Physiol. 228: 127-133.

18. Vurek, G. G., and S. E. Pegram. 1966. Fluorometric method for the determination of nanogram quantities of inulin. Anal. Biochem. 16:409-419.

19. Führ, J., J. Kazmarczyk, and C. D. Krüttgen. 1955. Eine einfache colorimetrische Methode zur Inulinbestimmung für NierenClearanceuntersuchungen bei Stoffwechselgesunden und Diabetikern. Klin. Wochenschr. 33:729-730.

20. Viets, J. W., W. M. Deen, J. L. Troy, and B. M. Brenner. 1978. Determination of serum protein concentration in nanoliter blood samples using fluorescamine or o-phthalaldehyde. Anal. Biochem. 88: 513-521.

21. Steiner, R. W., B. J. Tucker, and R. C. Blantz. 1979. Glomerular hemodynamics in rats with chronic sodium depletion. Effect of saralasin. J. Clin. Invest. 64:503-512.

22. Schor, N., I. Ichikawa, and B. M. Brenner. 1980. Glomerular adaptions to chronic dietary salt restriction or excess. Am. J. Physiol. 238:F428-F436.

23. Ichikawa, I., R. A. Ferrone, K. L. Duchin, M. Manning, V. J. Dzau, and B. M. Brenner. 1983. Relative contribution of vasopressin and angiotensin II to the altered renal microcirculatory dynamics in two-kidney Goldblatt hypertension. Circ. Res. 53:592-602.

24. Ploth, D. W. 1983. Angiotensin-dependent renal mechanisms in two-kidney, one-clip renal vascular hypertension. Am. J. Physiol. 245:F131-F141.

25. Tucker, B. J., and R. C. Blantz. 1983. Mechanism of altered glomerular hemodynamics during chronic sodium depletion. Am. J. Physiol. 244:F11-F18.

26. Huang, W.-C., D. W. Ploth, and L. G. Navar. 1982. Angiotensinmediated alterations in nephron function in Goldblatt hypertensive rats. Am. J. Physiol. 243:F553-F560.

27. Tucker, B. J., O. W. Peterson, M. G. Ziegler, and R. C. Blantz. 1982. Analysis of adrenergic effects of the anesthetics Inactin and $\alpha$ chloralose. Am. J. Physiol. 243:F253-F259.

28. Houck, P. C., M. J. Fiksen-Olsen, S. L. Britton, and J. C. Romero. 1983. Role of angiotensin and vasopressin on blood pressure of ganglionic blocked dogs. Am. J. Physiol. 244:H115-H120.

29. Zimpfer, M., W. T. Manders, A. C. Barger, and S. F. Vatner. 1982. Pentobarbital alters compensatory neural and humoral mechanisms in response to hemorrhage. Am. J. Physiol. 243:H713-H721.

30. Robertson, C. R., W. M. Deen, J. L. Troy, and B. M. Brenner. 1972. Dynamics of glomerular ultrafiltration in the rat. III. Hemodynamics and autoregulation. Am. J. Physiol. 223:1191-1200.

31. Beck, T. R., and M. J. Dunn. 1981. The relationship of antidiuretic hormone and renal prostaglandins. Miner. Electrolyte Metab. 6:46-59.

32. Zusman, R. M., and H. R. Keiser. 1977. Prostaglandin biosynthesis by rabbit renomedullary interstitial cells in tissue culture. Stimulation by angiotensin II, bradykinin and arginine vasopressin. J. Clin. Invest. 60:215-223.

33. Dunn, M. J., H. P. Greely, H. Valtin, L. B. Kinter, and R. Beeuwkes III. 1978. Renal excretion of prostaglandins $E_{2}$ and $F_{2 \alpha}$ in diabetes insipidus rats. Am. J. Physiol. 235:E624-E627.

34. Scharschmidt, L. A., and M. J. Dunn. 1983. Prostaglandin synthesis by rat glomerular mesangial cells in culture. Effects of angiotensin II and arginine vasopressin. J. Clin. Invest. 71:1756-1764.

35. Sraer, J., J. Foidart, D. Chancel, P. Mahieu, ánd R. Ardaillou. 1980. Prostaglandin synthesis by rat isolated glomeruli and glomerular cultured cells. Int. J. Biochem. 12:203-207.

36. Sraer, J., W. Siess, L. Moulonguet-Doleris, J. P. Oudinet, F. Dray, and R. Ardaillou. 1982. In vitro prostaglandin synthesis by various rat renal preparations. Biochim. Biophys. Acta. 710:45-52.

37. Oliver, J. A., R. R. Sciacca, G. Le Cren, and P. J. Cannon. 1982. Modulation by prostaglandins of the renal vascular action of arginine vasopressin. Prostaglandins. 24:641-656.

38. Zipser, R. D., S. I. Myers, and P. Needleman. 1981. Stimulation 
of renal prostaglandin synthesis by the pressor activity of vasopressin. Endocrinology. 108:495-499.

39. Beck, T. R., A. Hassid, and M. J. Dunn. 1980. The effect of arginine vasopressin and its analogs on the synthesis of prostaglandin $\mathrm{E}_{2}$ by rat renal medullary interstitial cells in culture. J. Pharmacol. Exp. Ther. 215:15-19.

40. Walker, L. A., A. R. Whorton, M. Smigel, R. France, and J. C. Frölich. 1978. Antidiuretic hormone increases renal prostaglandin synthesis in vivo. Am. J. Physiol. 235:F180-F185.

41. Danon, A., L. C. T. Chang, B. J. Sweetman, A. S. Nies, and J. A. Oates. 1975. Synthesis of prostaglandins by the rat renal papilla in vitro. Mechanism of stimulation of angiotensin II. Biochim. Biophys. Acta. 388:71-83.

42. Orloff, S., J. S. Handler, and S. Bergstrom. 1965. Effect of prostaglandin $\left(\mathrm{PGE}_{1}\right)$ on the permeability response of toad bladder to vasopressin, theophylline, and adenosine $3^{\prime}, 5^{\prime}$-monophosphate. Nature (Lond.). 205:397-398.

43. Grantham, J. J., and J. Orloff. 1968. Effect of prostaglandin $E_{1}$ on the permeability response of the isolated collecting tubule to vasopressin, adenosine $3^{\prime}, 5^{\prime}$-monophosphate, and theophylline. J. Clin. Invest. 47:1154-1161.

44. Beck, N. P., T. Kaneko, U. Zor, J. B. Field, and B. B. Davis. 1971. Effects of vasopressin and prostaglandin $E_{1}$ on the adenyl cyclasecyclic 3',5'-adenosine monophosphate system of the renal medulla of the rat. J. Clin. Invest. 50:2461-2465.

45. Marumo, F., and I. S. Edelman. 1971. Effects of $\mathrm{Ca}^{++}$and prostaglandin $\mathrm{E}_{1}$ on vasopressin activation of renal adenyl cyclase. $J$. Clin. Invest. 50:1613-1620.

46. Omachi, R. S., D. E. Robbie, J. S. Handler, and J. Orloff. 1974. Effects of ADH and other agents on cyclic AMP accumulation in toad bladder epithelium. Am. J. Physiol. 226:1152-1157.

47. Lum, G. M., G. A. Aisenbrey, M. J. Dunn, T. Berl, R. W. Schrier, and K. M. McDonald. 1977. In vivo effect of indomethacin to potentiate the renal medullary cyclic AMP response to vasopressin. J. Clin. Invest. 59:8-13.

48. Handler, J. S. 1981. Vasopressin-prostaglandin interactions in the regulation of epithelial cell permeability to water. Kidney Int. 19: 831-838. 